\title{
Contemporary Caitlín: Gender and Society in Celtic Tiger Popular Fiction
}

\section{Sorcha Gunne}

\section{(2) OpenEdition}

Journals

Electronic version

URL: https://journals.openedition.org/etudesirlandaises/3202

DOI: 10.4000/etudesirlandaises.3202

ISSN: 2259-8863

\section{Publisher}

Presses universitaires de Caen

Printed version

Date of publication: 30 October 2012

Number of pages: 143-158

ISBN: 978-7535-2158-2

ISSN: 0183-973X

\section{Electronic reference}

Sorcha Gunne, "Contemporary Caitlín: Gender and Society in Celtic Tiger Popular Fiction", Études irlandaises [Online], 37-2 | 2012, Online since 30 October 2014, connection on 27 July 2022. URL: http://journals.openedition.org/etudesirlandaises/3202 ; DOI: https://doi.org/10.4000/ etudesirlandaises.3202

This text was automatically generated on 27 July 2022

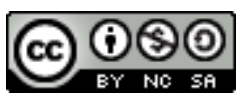

Creative Commons - Attribution-NonCommercial-ShareAlike 4.0 International - CC BY-NC-SA 4.0 https://creativecommons.org/licenses/by-nc-sa/4.0/ 


\title{
Contemporary Caitlín: Gender and Society in Celtic Tiger Popular Fiction
}

\author{
Sorcha Gunne
}

To fight men's battles for them and to neglect those of women has always been regarded as true womanly, though when men fight for their rights on the broad basis of humanity they are not accused of selfishness. The cause of the oppressed group is fully as great as that of an oppressed nation and deserves no taunt of narrowness ${ }^{2}$.

To make visible the lives of women and debate women's view of the world, we need to continually challenge not only patriarchal formulation of knowledge, but also the global patriarchal backlash which seems to claim we have entered the postfeminist era [...] I shall be a post-feminist only in post-patriarchy ${ }^{3}$.

1 I begin with a citation from the Irish suffragist Hanna Sheehy-Skeffington who, in turn, is referencing Mary Wollstonecraft in order to caution against the dangers of the subordination of women in nationalism. It is a poignant reminder of a historically tense, difficult and often contradictory relationship between women and nationalism in Ireland, and I begin with it because I think it still has resonance for us now: it speaks to the double bind that Irish women and Irish feminism has grappled with for a very long time. It strikes at the heart of what it meant, and perhaps what it still means, to be a woman in Ireland. Moreover, as the title of this paper indicates, I want to suggest that gender relations in Ireland are haunted by the spectre of the historical trope of woman as nation personified by Yeats's Caitlín (or Cathleen) Ní Houlihan ${ }^{4}$. Following this, Ronit Lentin's statement that she will be a post-feminist in a post-patriarchy is equally apposite as an epigraph to this paper because it is the position of women in contemporary Irish society that is the primary concern here.

2 There is a long list of Irish women writers like Anne Enright, Edna O'Brien and Anna Burns who write about contemporary Ireland in ways that challenge and resist dominant narratives, and who, in many respects, remain under-acknowledged by the critical literati $i^{5}$ Parallel to these authors there is a popular and prolific army of Irish chick lit writers such as Cecilia Ahern, Colette Caddle, Melissa Hill, Cathy Kelly, Marian 
Keyes, Sheila O'Flanagan, to name but a few ${ }^{6}$. The rise to prominence of Irish writers in the genre of chick lit roughly coincides with the Celtic Tiger. Coincides, but is not, I think, coincidental. For I agree with Sineád Kennedy's assertion that " $[t]$ he term "Celtic Tiger" has connotations that extend well beyond the realm of the purely economic. It has, for instance, become a metaphor for a new national consensus that constantly reminds us how "we have never had it so good'". The production, circulation and reception of chick lit in the Irish context, therefore, can be seen as a symbol of a new, more confident, economically and culturally independent Celtic Tiger-Ireland and it is this new, more confident, economically and culturally independent Ireland that is also its subject. Looking at the relationship between social, historical and economic constellations of woman and nation, I draw on Immanuel Wallerstein's thesis in "The Ideological Tensions of Capitalism: Universalism Versus Racism and Sexism" ${ }^{8}$ to contend that the Irish brand of Celtic Tiger chick lit was not post-feminist - nor is it even feminist - because it reactivates the spectre of the spéir-bhean to reaffirm patriarchal capitalism as the status quo ${ }^{9}$. This theoretical discussion is then followed by an examination of Melissa Hill's chick lit novel All Because of You (2007) ${ }^{10}$.

3 Change - economic, social and political - is crucial to understanding chick lit in the context of the Celtic Tiger, not least because these changes reflect the transformation of the position of women in Irish society. In this instance, Mary Robinson's election as president - Ireland's first female president - in 1990 is a commonly cited watershed moment. In 'Irish Women and the Celtic Tiger Economy', Kennedy offers an astute analysis that articulates several other factors that had a profound impact on Irish society. Acknowledging the positive effects of Ireland's succession to the EU and its increasing secularisation, she nonetheless posits that the cultural shift in the position of women can be "better understood if they are viewed in terms of the shifts in patterns of economic production. Changes in capitalism have resulted in a transformation of family structure, sex and sexuality, and, ultimately, the lives of Irish women. One of the defining features of the Celtic Tiger era has been the sheer number of women with children who are returning to the workforce ${ }^{11}$ ".

4 What Kennedy refers to as the feminisation of the workforce is undoubtedly a sign of political and social change. Perhaps it even necessitates a new type of fiction, such as chick lit which, according to Suzanne Ferriss and Mallory Young, 'features single women in their twenties and thirties "navigating their generation's challenges of balancing demanding careers with personal relationships" ${ }^{12}$ ". What I find most interesting about Kennedy's article, however, is that she firmly locates the feminisation of the workforce in a patriarchal capitalist world-system. In this sense, perhaps there has been an overemphasis on political, social and even economic change at the expense of a sustained engagement with the continuities of capitalism. In other words, the election of Mary Robinson signalled a change in Ireland. What is often overlooked, however, is the persistence of a deeply conservative tradition that remains committed to the patriarchal status quo $^{13}$ prompting Diarmaid Ferriter to ask "was [Robinson's] election a turning point in terms of women's successful involvement in Irish politics or was it a false dawn? ${ }^{14 "}$.

5 Ferriter's question cannot be divorced from the historical trope of woman because it is crucial to any understanding of contemporary gender relations in Irish society. I do not wish to rehearse here the well established critical terrain that documents, challenges and contests the allegorical function of woman in Irish nationalist discourse, culture 
and literature, chief examples of which are the work of Gerardine Meaney, Edna Longley, Catherine Nash and Elizabeth Butler Cullingford ${ }^{15}$. This argument can, however, be succinctly summed up by Nash's contention that "[c]ountless female embodiments of Ireland called on stage and page for Irish men to forsake their individual interests for the immortality of heroic sacrifice for the nation. In this embodiment, the female allegory was desexualised and venerated as a pure mother. Avowals of heroic masculinity were thus made alongside celebration of dependent, passive, domestic, and selfless Irish femininity" ${ }^{16 "}$.

What is relevant here, however, is the impact of these tropes. Meaney's 'Sex and Nation: Women in Irish Culture and Politics' is quite useful in this regard; in particular her recognition that no history can be complete, which allows her to develop a sophisticated critique of women and feminism in the Irish national imaginary. She is searching for a space in which women can achieve equality and citizenship, and in which there is a constant dialogue and communication within feminism and between feminisms and other disciplines that will challenge the misogynistic conventions of patriarchal history. At the same time, Meaney does not perceive women to be completely innocent in the process of their own subordination, asserting that "[i]f patriarchal history has portrayed us as bystanders, it has lied. We have always been implicated, even in our own oppression ${ }^{17 "}$. The role of women in their own suppression is part of the social conditioning of women and, perhaps, one of patriarchy's greatest successes. Meaney's theoretical stance here resonates with notions that are so embedded in cultural scaffolding so as to appear natural ${ }^{18}$. Where Meaney argues that, "patriarchy's strongest hold over women is its ability to promote this inner division, which inhibits women's will for change and recruits women damaged by patriarchal ideology to the cause of patriarchy itself and sets them campaigning and voting against their own interests ${ }^{19 "}$ ", Bourdieu contends that, "[i]f it is quite illusory to believe that symbolic violence can be overcome with the weapons of consciousness and will alone, this is because the effect and conditions of its efficacy are durably and deeply embedded in the body and in the form of dispositions ${ }^{20}$ ".

7 Meaney, moreover, explicitly intertwines feminist theory with postcolonial concepts ${ }^{21}$ in order to assess the increasingly marginalised position that women in Ireland found themselves in after independence: a marginalised position that was (and still is) enshrined in the Constitution ${ }^{22}$. Furthermore, she, like Bourdieu, seeks to reach an understanding as to why women are "recruited" for patriarchy. She argues that, "the language of patriarchy colonises women's self-concept and worldview. It presents the masculine as the norm and the feminine as aberration ${ }^{23}$." Symbolic violence results in women themselves becoming integral parts to the machine of patriarchy to such an extent that they are, in Meaney's words, "unable to accept themselves as thinking, choosing, sexual, intellectual and complex ordinary mortals and instead cling to the fantasy of women as simple handmaids of the lord ${ }^{24}$ ". The colonial power, furthermore, conceives of the colonised "other" as passive and in need of domination; thus, the male other, or the colonised male, is effeminised. This produces a sense of male anxiety with regards to their own sense of identity and often, as in the case of Ireland, results in a zealous focus on aggressive masculinity in nationalist contexts ${ }^{25}$. This perverse mimicry of colonial institutions of power, as Meaney argues, ultimately resulted in "the Irish obsession with control of women's bodies by church, State, boards of ethics and judicial enquiries ${ }^{26}$. Women's position of marginality was cemented because they represented the effeminate other that is so threatening to patriarchal power: whether that is the 
nationalist libertarian movement or the colonial oppressor ${ }^{27}$. A view echoed by Susan Cahill when she asserts that

The body, particularly bodies different from the white male heterosexual norm, became subject to repressive ideologies that resulted from the combination of discourse deriving from Catholic attitudes towards the corporeal and a postcolonialist mindset interested in establishing and maintaining an independent nation. The latter concern with the nation resulted in emphases on borders and ideas of purity which became focused on issues relating to the corporeal, particularly in terms of the family and the reproductive body. The 1937 Constitution sanctified the institution of the family and the mother's place within it and much feminist criticism has been focused on the persistent re-inscriptions of such allegories and the implications of these ideologies and legislations on the lived experience of womanhood in Ireland ${ }^{28}$.

As Meaney insightfully contends, "[w]omen in these conditions become guarantors of their men's status, bearers of national honour and the scapegoats of national identity' and, therefore, in Irish nationalism 'are not merely transformed into symbols of the nation. They become the territory over which power is exercised ${ }^{29 "}$.

Power-inflected gender relations in discourses of nationalism endure in modern Ireland though they were somewhat reconfigured by the Celtic Tiger. A trend recognised by Meaney in her more recent work where she asserts that, "[i]t might be assumed that the emergence of a prosperous post-Celtic Tiger Ireland would have eliminated the need for this kind of policing of the internal border constituted by women's bodies. In some regards that has been the case. In most important respects, however, the work of national scapegoat has simply been outsourced, as so much other domestic labour, onto immigrant women ${ }^{30}$ ". I agree with Meaney's statement up to a point; however, I maintain that while there has been a certain amount of outsourcing, the policing of Irish women's bodies continued throughout the Celtic Tiger. Meaney also usefully asserted that feminism and nationalism are not mutually exclusive and she articulates an urgent need for feminism to "interrogate nationalism" and the need for it to maintain "women's interests against any monolithic national identity which perpetuates patriarchy" ${ }^{31}$ ". Feminists must, therefore, as Meaney exhorts, actively debate the terms of nationalism in relation to constructs of 'woman' as this is the only way to break down the patriarchal structures that oppress women. They cannot do so, however, without examining the material conditions of contemporary capitalism. Patriarchy, simply put, does not operate in a vacuum; a point well made by the Egyptian psychiatrist and author Nawal El Saadawi who has suggested that patriarchy and capitalism are inherently linked, calling it the "global religion of patriarchal capitalism $^{32 "}$.

10 In scrutinising the interconnectedness of patriarchy and capitalism, the gendered makeup of the labour force is a useful site of analysis. Drawing on statics from the Central Statistics office and the National Household Survey, Kennedy outlines the radical and rapid changes that have occurred in the landscape of the Irish employment force: "[b]y 1996, there were 488,000 women working in Ireland, an increase of 212,000 since 1971, compared with an increase in male employment of just 23,000 for the same period. Between 1991 and 1996, female employment grew by 102,000, equalling the growth of the previous twenty years. A further 128,000 women entered the workforce between 1996 and $2000^{33}$." At a surface level these statistics portray a picture of women joining the workforce in droves and are apparent testimony to a positive Robinsoneffect. Kennedy, however, cautions against such a one dimensional reading of the data 
and notes the challenges faced by women entering the workforce, for example the gender pay gap and the burden of responsibility for household duties and childcare. The issue of domestic work is made all the more serious when the lack of state provision for adequate childcare and the high cost of private childcare are taken into account. The issue of the family and the division of domestic responsibilities is crucial here, for as Kennedy asserts:

On the surface, the family does not have an obvious economic role. While the conventional couple is usually presented in terms of individual romantic love, this should not obscure the family's economic function as a source of care and education for a future workforce in a crisis-ridden, profit-oriented system. Historically, it was women who were associated both with childcare and domestic labour and, while changes in capitalism have seen women enter the labour force, they still bear the primary responsibility for housework and childcare ${ }^{34}$.

11 Kennedy is, I think, correct in an analysis that looks beyond the ideology of romance and love to the importance of the role of the family in economic systems $\mathrm{s}^{35}$. What this highlights is the tension between the demands of the labour force on the one hand and the demands of the family on the other; and women entering the labour force en masse have unsettled not only traditional social gender relations, but the very foundation of capitalism itself.

The reason for this tension is explained by Immanuel Wallerstein as the fundamental contradiction that sustains and perpetuates capitalism. That is, the paradoxical inconsistency between doctrines of universalism proclaiming meritocratic equality on the one hand and systemic racism and sexism on the other. Wallerstein argues that in a capitalist world-system based on universalism where everything is reduced to commodification and profit one might expect racism and sexism to be eradicated, but in practise this is not the case. Instead, he notes how "if one wants to maximise the accumulations of capital, it is necessary to minimize the cost of production [...] and minimize the costs of political disruption [...]. Racism [and sexism] is the magic formula that reconciles these objectives ${ }^{36}$ ". This is a significant observation for gender relations because the family is the core unit of the capitalist world-system and it is worth quoting Wallerstein at some length here as he elaborates on his thesis:

In such a system, this labour input in nonwage work "compensates" the lowness of the wage-income and therefore in fact represents an indirect subsidy to the employers of the wage labourers in those households. Sexism permits us not to think about it. Sexism is not just the enforcement of different, or even less appreciated, work roles for women, no more than racism is just xenophobia. As racism is meant to keep people inside the work system, not eject them from it, so sexism intends the same [...]. The way we induce women [...] to work to create surplus-value for the owners of capital, who do not even pay them a little bit, is by proclaiming that their work is really nonwork. We invent the "housewife" and assert that she is not "working," merely "keeping house" [...] what we see, therefore, is a system that operates by a tense link between the right dosage of universalism and racism-sexism ${ }^{37}$.

The classification of domestic duties - household chores and childcare, for example - as the prerogative of women - as evidenced in the Irish Constitution's Article 41.2 - and at the same time as "nonwork" facilitates the smooth operation of capitalism by providing what amounts to free childcare for the next generation of workers. Thus, for Wallerstein, the apparent contradiction between universalism and racism-sexism in actual fact exposes the operational mechanisms of capitalism. Wallerstein's thesis not only makes sense of this contradictory logic; it is, I want to suggest, key to 
understanding gender relations in Ireland - especially when considered in relation to Bourdieu's thesis on symbolic violence - because it resolves the apparent conflict between the marginalisation of women in Irish public life on the one hand and the veneration of the Irish mother on the other. It illuminates the reasoning behind the Constitutional claim that a woman's place is in the home, and, furthermore, it indicates how the dramatic increase of women in the labour force in a relatively short space of time can have a destabilising impact. In this regard, it is not just the borders and boundaries of women's bodies that demand policing (as Meaney suggests), but also the position of women in society - not least the number of women who are engaged in wage labour, what kind of work they partake in and whether they work full- or parttime (i.e. whether they can work and execute their domestic duties).

It seems to me that the tension between family life and work life is the key element in an overwhelming number of chick lit novels. Alison Umminger has argued the opposite; namely that the fulcrum of the chick lit novel is not marriage: the "quest for a new partner is entirely secondary to the on-going battle chick lit's heroines are engaging with themselves ${ }^{38}$ ". This is, however, too simplistic a reading, because the quest for a partner and the "battle with themselves" are, in fact, implicated in the same schema. This message is not so subtly conveyed in the titles of quite a number of novels in the genre where ideas of love, marriage, fidelity and homecoming are foregrounded. For example: Maeve Binchy, Silver Wedding, Patricia Scanlon, Love and Marriage, Cathy Kelly, Homecoming, Marian Keyes, Lucy Sullivan is Getting Married and The Charming Man, Sheila o'Flanagan, Yours Faithfully and Isobel's Wedding, and Melissa Hill, All because of You. There is also a narrative arc that is frequently in evidence; one that, despite the main female protagonist having a career at the start of the novel, bears a striking resemblance to a traditional romance plot that culminates in marriage. In Feminism, Femininity and Popular Culture, Joanne Hollows draws on Ann Rosalind Jones' work on traditional romance to identify this as a narrative discontinuity or the contradiction that lies at the heart of chick lit: "the heroine shifts from being an independent and ambitious working woman to someone whose future is defined in terms of the hero", she continues, "for the love conflict to occupy centre stage, the job that gives the heroine glamour must always be temporary ${ }^{39 "}$.

In Melissa Hill's All Because of You, life coach Tara is the chief protagonist and the link between the other women in the novel: her best friend, Liz who is a housewife married to Eric; Natalie a career driven, successful public relations executive, who after meeting Tara on holidays becomes both friend and client; and Emma, Tara's younger sister who is pregnant but will not reveal the identity of her father. The intertwined lives of the four women unfold during the course of the novel. The novel can be described as a bildungsroman because during the course of the narrative the main characters come of age. For Tara and Natalie this means becoming part of a romantic relationship - Tara with Luke and Natalie with Jay/Jason; for, despite Umminger's claims to the contrary, as Elena Pérez-Serrano suggests, "Chick lit contains the all-pervasive idea that being in a relationship (and, on some occasions, getting married) is the most suitable option for women ${ }^{40}$. This point is also echoed by Pamela Butler and Jigna Desai in their article "Manolos, Marriage, and Mantras: Chick-Lit Criticism and Transnational Feminism" when they comment that, "For women's bildungsromans, this usually means a conclusion in which identity, status, and position are determined through proper marriage sanctioned by the family, society and, nation-state ${ }^{41}$ ". What is also striking 
about Hill's novel is that womanhood appears to be constructed entirely through motherhood: whether a central or peripheral character, the focus for all the women in the story is pregnancy and motherhood. Tara was a teenage mother whose son, Glenn, is now a teenager himself. Glenn's girlfriend, Abby, accidentally becomes pregnant. Emma, Tara's sister is also accidentally pregnant, as is Natalie's best friend, Freya. Liz is not pregnant, but has an eighteen- month old son. Natalie, notably in this regard, is not pregnant, but her reaction to the news of Freya's pregnancy is "pure and unadulterated jealousy ${ }^{42 "}$.

16 Because of her teenage pregnancy Tara seemingly deviates from the traditional romance story arc and is portrayed as a strong single mother who has fought to educate herself and get ahead in her career ${ }^{43}$. In this sense, she is compatible with the feminist ideal: she has seemingly rejected traditional marriage in favour of raising her son by herself and following a career trajectory ${ }^{44}$. Her career as a life coach, however, is in the traditional pastoral caring role ascribed to women, so although Tara is a successful woman with a career, her career blurs the line between work and "nonwork". Tara, for example, works from home, a fact which "seemed to put clients at ease. People mentioned they felt as though they'd just popped over to a friend's house for a cup of tea and a chat ${ }^{45}$ ". It seems to me that this "cosy atmosphere" also distinguishes Tara's job as a life coach from the profession of psychology. This is a distinction that Hill makes explicit a few lines later: "While there were links between therapy and life coaching, the latter had very different techniques and methodologies. Unlike psychology or psychiatry, coaching did not deal with diseases of body and mind - instead it helped with issues of self-esteem or inability to achieve goals ${ }^{46}$." The gap is clear. The professions of Psychology and Psychiatry deal with illness, whereas life coaches deal with emotional unhappiness. There is, therefore, an apparent tension between Tara, the professional go-getter and Tara, mother and carer. Hill's answer to this dilemma, it would appear, is to make Tara a professional friend of sorts.

17 Tara's best friend Liz, at the suggestion of her husband Eric, has moved to Castlegate, "a small picturesque and hugely popular tourist village 20 miles outside of Dublin city" where Eric and Tara grew up ${ }^{47}$. Eric appears to commute to work in Dublin, while Liz looks after their baby and runs a dog kennel from their "dream" home. Like Tara, Liz contributes to the household, but this does not usurp her ability to discharge her domestic duties. This blurring of the lines between public and private, professional and domestic is a familiar pattern seen elsewhere in chick lit novels. In Colette Caddle's The Secrets We Keep, for example, the protagonist, significantly named Erin, has left her unsuccessful life in the city and bought a guest house in the countryside ${ }^{48}$. In these cases, the narrative discontinuity picked up on by Hollows functions to reaffirm the patriarchal capitalist norm in a manner that resonates with Wallerstein's assessment and Article 41.2 of the Irish Constitution. The ideal woman has a job, but one that appeals to the traditional feminine qualities of nurturing and caring and, most importantly, allows her to foreground her domestic duties without rocking the patriarchal-capitalist boat. Furthermore, in All Because of You and The Secrets we Keep, as the names Tara and Erin implicitly suggest, these figures assume the characteristics of Caitlín, reactivating and re-appropriating the nationalist trope of mother Ireland in a contemporary context.

18 These characters can be juxtaposed with the go-getting, high-flying and glamorous career woman represented by English Natalie in Hill's All Because of You. Natalie has a 
successful career in London, but she commits the cardinal sin, so to speak, of trying to employ the same techniques that make her successful at work in her personal life ${ }^{49}$. This means that she displays the unfeminine characteristics of bossiness and pushiness; thus, all her romantic relationships are inevitably doomed to failure ${ }^{50}$. To remedy this, Natalie - the prodigal daughter - is 'coached' by Tara in order to be able to adopt a more suitably feminine demeanour and subsequently establish a romantically successful relationship. Natalie is driven to seek Tara's help because despite being a successful professional, she confesses "I know it's not fashionable to say it, and most of my single girlfriends in London would kill me for even thinking it, but it's what I want. I want to be married. I want to be somebody's wife ${ }^{51 "}$. This passage's confessional tone one of many similar confessions Natalie makes to Tara - is characteristic of the genre; as Ferriss and Young note: "Chick lit's narrative style furthers [...] claims to authenticity; established through the documentary text of the diary, the confessional style of letters, e-mails, and the intimacy of first-person narrative, this realism can result in the perception among readers that chick lit is not fiction at all ${ }^{52}$." Natalie's intimate confession to Tara functions similarly. This not only resonates because Irish social fabric is still intertwined with Catholicism and the concept of confession, but, in terms of gender politics, it implies that secretly all women want "to be somebody's wife".

Natalie - who is convinced every man she meets is "the one" - turns to Tara in order to make a potential relationship with Irishman Jay work. Her obsession with finding a husband is the dominant theme of Natalie's storyline - the very strong implication is that in order to feel personally fulfilled, she needs to fulfil a gendered social role as a wife and mother ${ }^{53}$. In another passage, she admits that she is too successful to attract a man, saying that she is not the "nicey-wifey" type, in other words, too independent:

When faced with a question like [why their relationships have not lasted] women often blamed themselves - their weight, their clothes, their attractiveness. But, she suspected, not this woman.

"I suppose some men might be quite frightened of me. Now, not wanting to blow my own trumpet here, but, as you know, I'm very successful in what I do. I have my own place here in London, a fantastic social life, lots of good friends and a bloody great lifestyle. So when it comes to men, perhaps I'm not really giving off the right vibes - you know, the 'nicey-wifey' type vibes. I think I might be too self-sufficient, too independent for them to think seriously about marrying me. And that's what I've been trying to change ${ }^{54 "}$.

Despite Tara's not very convincing claim that Natalie is not blaming herself for her romantic failures, this passage clearly evidences the element of symbolic violence embedded in chick lit narratives. Natalie can be a successful, independent woman, but to be a wife and a mother she must minimise these characteristics. This bears a striking resemblance to Pérez-Serrano's analysis of Marian Keyes' novel, Sushi for Beginners and the relationship between the protagonist, Lisa, and her husband, Oliver. Peréz-Serrano outlines how in this novel Oliver leaves Lisa because she is a workaholic. At the end of the novel, however, the pair are reconciled, but only because, as Peréz-Serrano contends, "Lisa's 'wrong' behaviour - that is to say, being more interested in her public than her private life - has been fixed and she has grown up, making it possible for Oliver to forgive her past mistakes and making their marriage viable again ${ }^{55}$. What Peréz-Serrano classifies as Lisa's "wrong behaviour" is similarly evident in Hill's depiction of Natalie and the reason she seeks out Tara as a life coach. Furthermore, Tara is sympathetic to Natalie's secret desire to be a wife and she has a significant 
symbolic role here as the confessor and, in this regard, her symbolic status as mother Ireland is emphasised.

Natalie's successful career in London adds an international appeal to the specificity of Ireland and Irishness in All Because of You. Indeed, many Irish chick lit novels explicitly court this internationalism; having links with America or, more commonly, London, such as Marian Keyes's Lucy Sullivan is Getting Married that is set in London - the Lucy of the title is the daughter of Irish immigrants. In their article, 'Manolos, Marriage, and Mantras: Chick-Lit Criticism and Transnational Feminsim,' Pamela Butler and Jigna Desai argue that, "In dominant white chick lit [...] not only does the white protagonist join the nation through her desire for consumption and for marriage, but she is willing and desires to become a global citizen as well - her transnational travel and consumption, as well as her location in a Western global city such as London, New York, or Los Angeles, mark her as a cosmopolitan subject who is easily able to cross borders and cultures ${ }^{56 "}$. In All Because of You, Natalie's London location underscores the success of her career. In the specific context of Ireland's location in a world-system, however, this link with London as a cosmopolitan centre has several different levels of significance; primarily because it complicates the gender politics at play by incorporating issues that relate to colonial and postcolonial power dynamics. In the colonial/postcolonial context, London is the imperial centre. This informs a place-sense that constructs Ireland, not just in terms of a past Golden Age, but as the pastoral, rural Other. As Raymond Williams theorises in The Country and the City: "On the country has gathered the idea of a natural way of life: of peace, innocence, and simple virtue. On the city has gathered the idea of achieved centre: of learning, communication, light. Powerful hostile associations have also developed: on the city as a place of noise, worldliness and ambition; on the country as a place of backwardness, ignorance ${ }^{57}$." Discussing Greek and Latin literature, Williams observes "This powerful satire of a corrupt city life has had an extraordinary influence in subsequent literature; and it has been re-experienced, without influence, in many places and generations"; and so it emerges in chick lit ${ }^{58}$. The idea of urban centre and rural other, moreover, is important, because it is a key indicator as to how chick lit, as a genre, constructs the modern Irish woman not least because it gestures to the idea of home and domesticity: Ireland as "home" in relation to London; and the countryside (outside Dublin) as "home" within Ireland. In Hill's novel, the imperial city - London - has seemingly corrupted Natalie and this is contrasted with the pastoral ideal of Liz's domestic situation.

Liz, moreover, in contrast to Natalie, is the "nicey-wifey" type and is described as "docile and unassuming ${ }^{59 "}$. This is nowhere more in evidence than when she suspects her husband is having an affair. She is wracked with jealously, but instead of talking to him about it, she tries to suppress her concerns: "A wildly jealous woman wasn't attractive, Liz knew that, and so she'd always taken great pains to ensure her insecurities remained hidden ${ }^{60}$." The vocabulary deployed here, like Natalie's confession, is striking. It again resonates with Peréz-Serrano's analysis of Keyes's writing, this time with Angels (2002). Peréz-Serrano notes that in Angels, "[d]espite her husband's infidelity and the feeling of frustration brought about by the difficulties in their relationship, Maggie reaches the end of the story convinced that the security of a marriage is the greatest achievement in life. In spite of any miseries that her union might have brought with it, the prevailing message is that getting married provides further stability and satisfaction than any other alternative ${ }^{61 "}$. That Eric is not having 
an affair is irrelevant, because, presumably, the primary goal is to remain attractively appealing and ideal in the eyes of her husband, regardless of his fidelity or lack thereof; demonstrating how - recalling Nash's argument - Irish womanhood is still celebrated as dependent, passive, domestic and selfless: as pure motherhood. Perhaps, though, what is most troubling is not that marriage is the ultimate goal for the 21st century woman, but the type of marriage that Liz, Natalie and even Tara - along with Caddles's Erin and Keyes's Lisa and Maggie - imagine. This is not a picture of marriage that is "between two equals who value and cherish each other in a relationship that emphasizes romance

and communication ${ }^{62}$, but rather reflects the ideals of patriarchal capitalism.

The consequence of the redeployment of the trope of woman as nation or mother Ireland is that it not only perpetuates a metaphorical myth about Irish identity, but far more importantly, it has tangible and material consequences for contemporary Irish society. Re-animating the allegorical image of Caitlín Ní Houlihan in novels like All Because of You reasserts - both implicitly and explicitly - the atavistic claim in the Constitution that a woman's place is in the home. The domino effect of this is profound for individual and collective reproductive rights; childcare; labour and employment markets; and personal relationships. The trend in Irish chick lit to establish a narrative arc that results in normative heterosexual relationships is worrying primarily because of the type of relationship that is being imagined: a return to the rural domestic ideal of yesteryear where contemporary women do not sacrifice their careers for love, marriage, children and rural domestic bliss; they are instead fulfilled by it, because as Natalie confesses it is what she really wanted all along. In this constellation, the structures of patriarchy and capitalism are not put at risk by women's entry into the workforce because their participation has limitations. Anecdotally, I have heard people - mostly women - claim that they like to read chick lit to "switch off". We should, however, as the adage goes, not judge a book by its cover; and, it would seem to me, the underlying message of these novels is far less benign than the bright coloured covers suggest. Instead of being funny post-feminist fiction, I think it is not unreasonable to suggest that they constitute a form of symbolic violence that reaffirms patriarchal-capitalist norms. Hence Lentin's proclamation, "I'll be a post-feminist only in a post-patriarchy", is more important than ever.

\section{NOTES}

2. Hanna Shechy-Skeffington, in Declan Kiberd, Inventing Ireland: The Literature of a Modern Nation, London, Vintage, 1996, p. 397.

3. Ronit Lentin, "'I'll be a Post-Feminist in Post Patriarchy': Reflexivity is a Feminist Issue", R. Tormey, A. Good and C. MacKeogh (eds), Post-methodology: New Directions for Research Methodologies in the Social Sciences, Dublin, Department of Sociology, Trinity College Dublin, 1994, HTTP available at: [www.iol.ie/ mazzoldi/toolsforchange/postmet/ feminist.html]. Date accessed: 23.2.2011. 
4. William Butler Yeats, Cathleen Ní Houlihan, London, A.H. Bullen, 1906.

5. Susan Cahill also makes this point in Irish Literature in the Celtic Tiger Years 1990-2008: Gender, Bodies, Memory, London, Continuum, 2011. She notes Anne Haverty's The Free and Easy (2007) and also cites Éilís Ní Dhuibhne's letter to the Irish Times (2010) in which Ní Dhuibhne cites a long list of women writers who are writing literary fiction about the Celtic Tiger: Nuala O'Faolain; Almost There, Mary Rose Callaghan, Billy Come Home; Lia Mills, Nothing Simple; Catherine Dunne, Set in Stone; Jennifer Johnston, Truth or Fiction; Claire Kilroy, All Names have been Changed and herself, for example, p. 13-14.

6. This is not to suggest that all chick lit is Irish. I am, however, concerned with Irish writers in this essay because it seems to me that while they have international appeal Irish writers are drawing on specifically Irish circumstances, such as the Celtic Tiger and myths of Irish womanhood; therefore, I refer to it here as the Irish brand of chick lit.

7. Sineád Kennedy, "Irish Women and the Celtic Tiger Economy", Colin Coulter and Steve Coleman (eds), The End of Irish History? Critical Reflections on the Celtic Tiger, Manchester, Manchester University Press, 2003, p. 95-109, p. 95. Declan Kiberd notes that, "[i]n strict linguistic terms, the Celtic Tiger was born in 1994, when David McWilliams, a young Irish dealer at the Banque Nationale de Paris, used the phrase in a report on the Irish economy" (Declan Kiberd, The Irish Writer and the World, Cambridge, Cambridge University Press, 2005, p. 271).

8. Immanuel Wallerstein, "The Ideological Tensions of Capitalism: Universalism Versus Racism and Sexism", The Essential Wallerstein, New York, New Press, 2000, p. 344-352; Cahill 2007.

9. Similar to Cathleen Ní Houlihan, the spéir-bhean, or sky-woman, was the metaphorical figure of Ireland characteristic of 18th-century aisling, or dream, poems. Also see Catherine Nash, "Embodied Irishness: Gender, Sexuality and Irish Identities", Brian Graham (ed.), In Search of Ireland: A Cultural Geography, New York, Routledge, 1997, p. 108-127.

10. Melissa Hill, All Because of You, London, Arrow, 2007. The next obvious step is to conduct a distant reading analysis of the kind advocated by Franco Moretti in "Conjectures on World Literature", Christopher Prendergast (ed), Debating World Literature, London, Verso, 2004, p. 148-162. Such a study, however, is outside the scope of this article.

11. Kennedy, op. cit., p. 95.

12. Suzanne Ferriss and Mallory Young, Chick Lit: The New Woman's Fiction, New York, Routledge, 2006, p. 3.

13. In April 2012 the dogged persistence of conservative thinking in Ireland was clearly evidenced in a Dáil debate concerned with a Private Members' Bill that sought to implement the X case ruling of 1992 and provide limited access to abortion in Ireland where a woman's life is at risk. The bill was defeated 111 votes to 20. Furthermore, during this debate Fine Gael TD Michelle Mulherin commented that "fornication" was the single greatest cause of unwanted pregnancies in Ireland. Michael O'Regan and Marie O'Halloran, "TDs reject abortion Bill vote", The Irish Times, 19th April 2012, HTTP available at: [http://www.irishtimes.com/newspaper/breaking/2012/0419/breaking14.html], Date accessed: 2.5.2012. Also see Kathryn A. Conrad, "Fetal Ireland: Reproduction, Agency and Irish National Discourses", Locked in the Family Cell: Gender, Sexuality, and 
Political Agency in Irish National Discourse, Madison, the University of Wisconsin Press, 2004.

14. Diarmaid Ferriter, "Women and Political Change in Ireland since 1960", Éire-Ireland, 43.1\&2, 2008, p. 179-204, p. 201.

15. Examples of work specifically addressing the notion of the eponymous Cathleen Ní Houlihan are: Edna Longley From Cathleen to Anorexia: The Breakdown of Irelands, Dublin, Attic Press, 1990; Catherine B. Shannon, "The Changing Face of Cathleen ni Houlihan: Women and Politics in Ireland, 1960-1996", Anthony Bradley and Maryann Gialanella Valiulis (eds), Gender and Sexuality in Modern Ireland, Amherst, Mass., University of Massachusetts Press, 1997, p. 257-274; and Jennifer Grinnell and Alston Conley (eds), Re/Dressing Cathleen: Contemporary Works from Irish Women Artists, Chestnut Hill, MA, McMullen Museum of Art/Boston College, 1997.

16. Nash, op. cit., p. 114. For a discussion on the changing nature of sexuality in Ireland also see Dympna McLoughlin, "Women and Sexuality in Nineteenth-Century Ireland", Irish Journal of Psychology, 15.2-3, 1994, p. 266-275.

17. Gerardine Meaney, "Sex and Nation: Women in Irish Culture and Politics", Ailbhe Smyth (ed.) Irish Women's Studies Reader, Dublin, Attic Press, 1993, p. 230-244, p. 238.

18. Pierre Bourdieu, Masculine Domination (Trans. Richard Nice), Stanford, Stanford University Press, 2001, p. 34. Bourdieu is careful to note that his deployment of the term "symbolic" is not merely in the sense of "spiritual" violence that is opposite to "real" or "actual". Conversely, his formulation of symbolic violence can have epistemological effects and physical or material effects because it refers to "the subjective experience of relations of domination", idem.

19. Meaney, "Sex and Nation: Women in Irish Culture and Politics", op. cit., p. 231.

20. Bourdieu, op. cit., p. 39.

21. Irish feminism's difficult relationship with postcolonial studies is discussed by Emer Nolan in "Postcolonial Literary Studies, Nationalism, and Feminist Critique in Contemporary Ireland", Éire-Ireland, 42: 1\&2, 2007, p. 336-361.

22. Article 41.2.1 ${ }^{\circ}$ states: "In particular, the State recognises that by her life within the home, woman gives to the State a support without which the common good cannot be achieved" followed by Article 41.2.2 : "The State shall, therefore, endeavour to ensure that mothers shall not be obliged by economic necessity to engage in labour to the neglect of their duties in the home". HTTP available at: [http://www.constitution.ie/ constitution-of-ireland/default.asp?UserLang=EN ]Date accessed: 4.5.2012.

23. Meaney, "Sex and Nation: Women in Irish Culture and Politics", op. cit., p. 241.

24. Ibid., p. 231.

25. Anne McClintock, Imperial Leather: Race, Gender, and Sexuality in the Colonial Conquest, New York, Routledge, 1995.

26. Meaney, "Sex and Nation: Women in Irish Culture and Politics", op. cit., p. 233.

27. Ibid., p. 234.

28. Cahill, op. cit., p. 15-16.

29. Meaney, "Sex and Nation: Women in Irish Culture and Politics", op. cit., p. 233.

30. Gerardine Meaney, Gender, Ireland and Cultural Change: Race, Sex and Nation, New York, Routledge, 2010, p. 4-5 and 65-66. 
31. Meaney, "Sex and Nation: Women in Irish Culture and Politics", op. cit., p. 237.

32. El Saadawi made this comment during a talk at Housmans Bookshop in April 2009. HTTP available at: [

http://www.youtube.com/watch?

$v=F 3 P S M C O g n h 4 \&$ list $=F L 4 K I 1 \times F o K B a C f T a g 7 E 0 c c 4 Q \&$ index $=5 \&$ feature $=p l p p \_v i d e o$

] Date accessed: 7.1.2012.

33. Kennedy, op. cit., p. 95.

34. Kennedy, op. cit., p. 105. Also see J. Baxter, B. Hewitt \& M. Western, "Post-familial Families and the Domestic Division of Labor", Journal of Comparative Family Studies, 36.4, 2005, p. 583-600; R. Beaujot \& J. Liu, "Models of Time Use in Paid and Unpaid Work", Journal of Family Issues, 26, 2005, p. 924-946; A. R. Hochschild, The Second Shift, New York, Avon Books, 1989; Y-S Lee \& L. Waite, "'Husbands" and Wives' Time Spent in Housework: A Comparison of Measure", Journal of Marriage and Family, 67, 2005, p. 328-336.

35. In Feminism, Femininity and Popular Culture, Joanne Hollows notes how second wave feminists like Kate Millet and Stevi Jackson saw love as "an ideology which legitimated women's oppression and which trapped them into exploitative heterosexual relationships": Joanne Hollows, Feminism, Femininity and Popular Culture, Manchester, Manchester University Press, 2000, p. 72.

36. Wallerstein, op. cit., p. 348-349.

37. Ibid., p. 350-351.

38. Alison Umminger, "Supersizing Bridget Jones: What's Really Eating the Women in Chick Lit", p. 239-252. Ferriss and Young, op. cit., p. 11

39. Hollows, op. cit., p. 204-207.

40. Elena Pérez-Serrano, "Chick Lit and Marian Keyes: The ideological background of the genre", Sarah Gormley and Sara Mills (eds), Chick Lit: Working Papers on the Web 13, 2009. HTTP available at: [

http://extra.shu.ac.uk/wpw/chicklit/perezserrano.html

]. Date accessed: 27.4.2012.

41. Pamela Butler and Jigna Desai, "Manolos, Marriage, and Mantras: Chick-Lit Criticism and Transnational Feminsim", Meridians: Feminism, Race, Transnationalism, 8.2, 2008, p. 1-31, p. 15.

42. Hill, op. cit., p. 172.

43. Ibid., p. 378-387.

44. Ibid., p. 22.

45. Ibid., p. 12.

46. Idem.

47. Ibid., p. 19.

48. Colette Caddle, The Secrets We Keep, Oxford, Isis, 2009, 2010.

49. Hill, op. cit., p. 146.

50. Her pushiness leads one boyfriend to call her a 'psycho bunny-boiler', ibid., p. 142.

51. Ibid., p. 116, original italics.

52. Ferriss and Young, op. cit., p. 6. 
53. Hill, op. cit., p. 71, 80, 116, 137, 176, 242, 251.

54. Ibid., p. 249.

55. Peréz-Serrano, op. cit., online.

56. Butler and Desai, op. cit., p. 19.

57. Raymond Williams, The Country and The City, London, Hogarth Press, 1973, 1985, p. 1.

58. Ibid., p. 47.

59. Ibid., p. 207.

60. Hill, op. cit., p. 129.

61. Peréz-Serrano, op. cit., online.

62. Butler and Desai, op. cit., p. 16.

\section{ABSTRACTS}

This article explores the ways in which the traditional trope of Cathleen Ni Houlihan continues to haunt some contemporary Irish women's novels. Focusing on recent "chick lit", the fraught relations between gender and nationalism are analysed with a view to questioning the very possibility of embracing "post-feminism" in a context in which some women's literature, far from challenging the patriarchal and capitalist status quo, actually perpetuates it.

Cet article se propose d'étudier la manière dont le trope traditionnel de Cathleen Ni Houlihan continue de hanter les romans contemporains de certaines auteures irlandaises. A partir d'une analyse de la littérature populaire pour femmes ( chick lit»), les relations tendues entre genre et nationalisme seront examinées afin d'interroger la recevabilité même du terme "postféminisme » dans un contexte où la littérature de certains auteures, très loin de remettre en cause le statu quo patriarcal et capitaliste, continue de le renforcer.

\section{INDEX}

Mots-clés: littérature populaire, études de genre, femmes - représentations littéraires, contes et légendes, féminisme et post-féminisme, Ni Houlihan Cathleen

Keywords: chick lit, gender studies, feminism and post-feminism, tales and legends, Ni Houlihan Cathleen, women - literary representations

\section{AUTHOR}

\section{SORCHA GUNNE}

Warwick University 